\title{
Nanostructured Materials and Nanotechnology
}




\section{MATERIALS RESEARCH SOCIETY \\ SYMPOSIUM PROCEEDINGS VOLUME 1371 \\ Nanostructured Materials and Nanotechnology}

\section{EDITORS}

Claudia Gutiérrez-Wing

Instituto Nacional de Investigaciones Nucleares

Ocoyoacac, México

\section{José Luis Rodríguez-López}

Instituto Potosino de Investigación Científica y Tecnológica

San Luis Potosí, México

\section{Olivia A. Graeve}

Alfred University

Alfred, NY, USA

John J. Boeckl

Air Force Research Laboratory

Wright-Patterson Air Force Base, OH, USA

\section{Patrick Soukiassian}

Université de Paris-Sud, Orsay Commissariat à l'Energie Atomique et aux Energies Alternatives, Saclay, France

\section{$\mathrm{M}|\mathrm{R}| \mathrm{S}$}

Materials Research Society

Warrendale, Pennsylvania

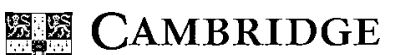

UNIVERSITY PRESS 
CAMBRIDGE UNIVERSITY PRESS

Cambridge, New York, Melbourne, Madrid, Cape Town,

Singapore, São Paulo, Delhi, Mexico City

Cambridge University Press

32 Avenue of the Americas, New York, NY 10013-2473, USA

www.cambridge.org

Information on this title: www.cambridge.org/9781605113500

Materials Research Society

506 Keystone Drive, Warrendale, PA 15086

http://www.mrs.org

(c) Materials Research Society 2012

This publication is in copyright. Subject to statutory exception and to the provisions of relevant collective licensing agreements, no reproduction of any part may take place without the written permission of Cambridge University Press.

This book has been registered with Copyright Clearance Center, Inc. For further information please contact the Copyright Clearance Center, Salem, Massachusetts.

First published 2012

\section{CODEN: MRSPDH}

ISBN: 978-1-60511-350-0 Hardback

Cambridge University Press has no responsibility for the persistence or accuracy of URLs for external or third-party Internet Web sites referred to in this publication and does not guarantee that any content on such Web sites is, or will remain, accurate or appropriate. 


\section{CONTENTS}

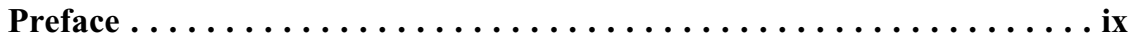

Materials Research Society Symposium Proceedings........... xi

Size and Shape Dependencies of Nanomaterial Properties:

Thermodynamic Considerations. ......................

Grégory Guisbiers

Synthesis of Silver Nanostructures by the Polyol Method

and their Statistical Analysis Using Design of Experiments. . . . . . . .

Jaime E. Pérez, Adriana B. Arauz,

Luis A. García, and José L. Rodríguez

Characterization of Electron-Beam-Induced Silver Deposition

from Liquid Phase ............................

Jonathan J. Park, Alexandra Joshi-Imre,

Leonidas E. Ocola, and Ralu Divan

Synthesis of Soluble Carcerands. ......................19

I. Eddy Jiménez-Gutiérrez, K. Erika Sánchez-Montes,

Sandra Cortez-Maya, Gabriel Flores-Rojas,

and Marcos Martínez-García

Near-Equilibrium Solubility of Nanocrystalline Alloys ..........27

Alexander Kirchner, Thomas Riedl, Konrad Eymann,

Michael Noethe, and Bernd Kieback

VLS Synthesis and Characterization of $\mathrm{SnO}_{2}$ Nanowires. .........33

Dulce N. Castillo, Tomás D. Becerril,

Enrique R. Andrés, Héctor J. Santiesteban,

and Godofredo G. Salgado

$\mathrm{ZrO}_{2}$ Nanopowders Doped with Eu: SEM, XRD

and UV Spectroscopy Studies.......................39

Gerardo Villa Sánchez, Demetrio Mendoza Anaya,

Emmanuel Palma Palma, Claudia E. Gutiérrez Wing,

Raúl Pérez Hernández, Oscar F. Olea Mejía,

and Federico García Santibañez 
Raman Spectrum Modification of CdSe/ZnS Quantum

Dots at the Bio-conjugation to IgG Antibodies. .

A.I. Diaz Cano, J. Douda, C.R. Gonzalez Vargas, and K. Gazarian

Effect of Titania Grafting on Behavior of NiMo HDS

Catalysts Supported on Nanostructured Silica Materials..........51

A. Mendoza-Nieto, I. Puente-Lee,

C. Salcedo-Luna, and T. Klimova

Integrating Carbon Nanotubes into Microfluidic

Chips for Separating Biochemical Compounds . . . . . . . . . . . .57

Miaoxiang Chen, Klaus B. Mogensen,

Peter Boggild, and Jörg P. Kutter

Characterization of Dispersion of Carbon Nanotubes

in Polymer Matrices..........................63

Laura Peña-Parás, Hubert Phillips III, and Enrique V. Barrera

Polymer Nanohybrids with High Electrical Conductivities

R. Yañez-Macías, P. González-Morones,

C. Ávila-Orta, S. Torres-Rincón,

J. Valdéz-Garza, A. Rosales-Jasso,

J.G. Telles-Padilla, and A. Saénz-Galindo

Study of Fracture Behavior of Polypropylene/MWCNT and Polypropylene/m-MMT Nanocomposites by Small

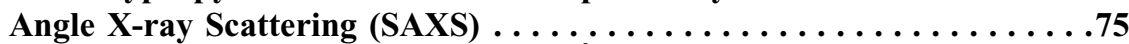

José. M. Mata-Padilla, Carlos. A. Ávila-Orta,

Francisco. J. Medellín-Rodríguez,

Janet. A. Valdéz-Garza,

and Adriana Torres-Martínez

Halide Ion Effect in Shape Transformation from Silver

Triangular Nanoprisms to Silver Nanodisks . . . . . . . . . . . 81

Israel A. López, and Idalia Gómez

Shape and Stability of Silver Nanoparticles and their

Dependence on the Conditions of Preparation.

M.I. Hernández-Castillo, O. Zaca-Moran,

P. Zaca-Moran, M. Rojas-López, V.L. Gayou,

R. Delgado-Macuil, and A. Orduña-Díaz 
Theoretical Study of Alkanedithiolated Gold Clusters.............91

J.M. Cabrera-Trujillo, and R. Jiménez-Cataño

Development and Characterization of Nanocomposites

with Gold Nanoparticles Embedded in the Nanostructured

Silicon Substrate. ................................99

V.L. Gayou, A. Orduña Diaz,

R. Delgado Macuil, M. Rojas López,

J.A. Andraca-Adame, and Vivechana Agarwal

$\mathrm{ZrO}_{2}$ Doped with Cobalt Nanoparticles to Detect UV Radiation......105

Gerardo Villa Sánchez, Demetrio Mendoza Anaya,

Claudia Gutiérrez-Wing, Pedro R. González Martínez.,

and Oscar F. Olea Mejía

Effect of Organoclay's Characteristics During the Preparation

of Complex Ternary System PP-EP/EVA/Organoclay. . . . . . . . .111

Olivares M. Yeraldin, Ramírez V. Eduardo, and Sánchez V. Saúl

Influence of Oxide Nanoparticles of $\mathrm{Fe}, \mathrm{Al}$ and $\mathrm{Si}$ on the Sintered Magnesia for the Production of Refractory

Material to be Used in Secondary Ladle Metallurgy . . . . . . . . . . 117

Cristian Gómez, Tushar. K. Das,

Sadasivan Shaji, Edén A. Rodríguez,

Ana M. Guzmán, Alan Castillo,

and Laura García

Features of Formation of Composite Nanopowders

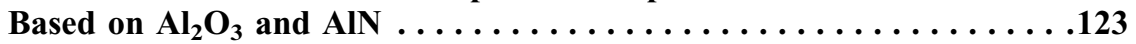

M. Vlasova, P.A. Márquez Aguilar,

M. Kakazey, V. Stetsenko, A. Bykov,

and T. Tomila

Transmission of Dirac Electrons Through Graphene

Multilayers with Gaussian Profile .....................129

J.A. Aguilar-Hernández, J. Madrigal-Melchor,

J.C. Martínez-Orozco, and I. Rodríguez-Vargas

Transmission for a Finite Superlattice with a Linear Modulation

of the Potential Barriers Height.

K.A. Rodríguez-Magdaleno,

J.C. Martínez-Orozco,

and D.A. Contreras-Solorio 
Transmission Properties of Multilayered Period Doubling

and Silver-Mean Graphene Structures.

G. Rodríguez-Arellano, D.P. Juárez-López,

J. Madrigal-Melchor, R. Pérez-Álvarez,

J.C. Martínez-Orozco, and I. Rodríguez-Vargas

Author Index

Subject Index $\ldots \ldots \ldots \ldots \ldots \ldots \ldots \ldots \ldots \ldots \ldots \ldots \ldots \ldots \ldots$ 


\section{PREFACE}

The fields of nanoscience and nanotechnology continue to have a major impact in a number of scientific and technological areas such as health, computing, sensing, catalysis, coatings and aerospace, just to mention a few. For the past few years, the Nanostructured Materials and Nanotechnology Symposium during the International Materials Research Congress, has been aiming to provide an international forum for the presentation of the latest developments in nanotechnology and nanomaterials research. In the 2011 edition, as in previous years, a growing community of scientists, researchers, students and industry representatives, have gathered to present and discuss the different topics covered by the symposium, which range from theory to experiment and include new synthetic routes, processing, characterization and modeling of nanomaterials, structure-property correlations at the nanoscale, fundamental phenomena occurring in nanoscale systems and processes, and the design, application and industrial development of nanostructured materials and nanosystems.

This year the symposium also included a session devoted specifically to low dimensional carbon nanostructures, as they are at the forefront of materials research and exhibit novel properties with potential applications in high speed nano-electronics, high performance composites for mechanical, electrical and thermal applications, high efficiency photovoltaics, and field emitters. In this MRS proceedings volume, we have compiled a number of papers, which discuss representative state-of-the-art topics covered by the Nanostructured Materials and Nanotechnology Symposium. Interesting and high quality contributions have been collected, which include theoretical studies on the properties of nanomaterials, the synthesis of metallic nanostructures and nanocomposites, studies on graphene and carbon nanotubes, applications of nanomaterials as UV detectors, biomarkers and catalysis.

We hope you will find this compilation interesting, informative and inspiring for further discussion and for the advancement of the fields of nanoscience and nanotechnology.

The editors

MRS Proceedings / Nanostructured Materials and Nanotechnology Symposium XX IMRC

Claudia Gutiérrez-Wing

José Luis Rodríguez-López

Olivia A. Graeve

John J. Boeckl

Patrick Soukiassian 


\section{Materials Research Society Symposium Proceedings}

Volume 1371 - Nanostructured Materials and Nanotechnology, C. Gutiérrez-Wing, J.L. Rodríguez-López, O.A. Graeve, J.J. Boeckl, P. Soukiassian, 2012, ISBN 978-1-60511-348-7

Volume 1372 - Structural and Chemical Characterization of Metals, Alloys, and Compounds - 2011, R. Pérez Campos, A. Contreras Cuevas, R.A. Esparza Munoz, 2012, ISBN 978-1-60511-349-4

Volume 1373 - Advanced Structural Materials - 2011, H.A. Calderon, A. Salinas Rodriguez, H. Balmori Ramirez, 2012, ISBN 978-1-60511-350-0

Volume 1374 - Cultural Heritage and Archaeological Issues in Materials Science, J.L. Ruvalcaba Sil, J. Reyes Trujeque, A.Velazquez Castro, M. Espinosa Pesqueira. 2012, ISBN 978-1-60511-351-7

Volume 1376E - Biomaterials for Medical Applications, S. Rodil, A. Almaguer, K. Anselme, 2012, ISBN 978-1-60511-353-1

Volume 1380E - Materials Research for Mining and Mineral Processing, F.R.C. Pedroza, 2012, ISBN 978-1-60511-357-9

Volume 1381E - Materials Welding and Joining Technologies, F.A.R. Valdes, 2012, ISBN 978-1-60511-358-6

Volume 1383 - Material Challenges in Current and Future Nuclear Technologies, K.R. Whittle, M. Bertolus, B. Uberuaga, R.W. Grimes, 2011, ISBN 978-1-60511-360-9

Volume 1384E - Advanced Materials for Fuel Cells, J. Hertz, M.L. DiVona, P. Knauth, H.L. Tuller, 2011, ISBN 978-1-60511-361-6

Volume 1385E - In-Situ Studies of Solid-Oxide Fuel-Cell Materials, R. Maher, 2011, ISBN 978-1-60511-362-3

Volume 1386E - Sustainable Synthesis of Nanomaterials, H. Fan, M. Knez, S.S. Wong, W. Lee, 2011, ISBN 978-1-60511-363-0

Volume 1387E - Advanced Materials for Solar-Fuel Generation, C. Hill, 2011, ISBN 978-1-60511-364-7

Volume 1388 - Mobile Energy, S. Mhaisalkar, K. Shenai, G. Amaratunga, A. Nathan, 2011, ISBN 978-1-60511-365-4

Volume 1389E - Applications of Hierarchical 3D Structures, J.H. Moon, S. Jeon, S. Yang, R.A. Vaia, 2011, ISBN 978-1-60511-366-1

Volume 1390 - Organic Photovoltaics-Materials to Devices, V. Bommisetty, G. Li, C. Deibel, T-Q. Nguyen, D.C. Olson, M. Riede, M. Leclerc, V. Dyakonov, G. Rumbles, N.S. Sariciftci, 2011, ISBN 978-1-60511-367-8

Volume 1391E - Photonic and Plasmonic Materials for Enhanced Photovoltaic Performance, R. Biswas, 2011, ISBN 978-1-60511-368-5

Volume 1392E - Materials for High-Performance Photonics, T.M. Cooper, S.R. Flom, M. Bockstaller, C. Lopes, 2011, ISBN 978-1-60511-369-2

Volume 1393E - Topological Insulator Materials, C. Felser, Y. Cui, H. Peng, S. Murakami, 2011, ISBN 978-1-60511-370-8

Volume 1394E - Oxide Semiconductors-Defects, Growth and Device Fabrication, T. Veal, S. Durbin, J. Phillips, M. Grundmann, 2011, ISBN 978-1-60511-371-5

Volume 1395 - Diamond Electronics and Biotechnology-Fundamentals to Applications V, O.A. Williams, R.B. Jackman, P. Bergonzo, G.M. Swain, K.P. Loh, 2011, ISBN 978-1-60511-372-2

Volume 1396 - Compound Semiconductors for Generating, Emitting and Manipulating Energy, T. Li, M. Mastro, A. Dadgar, H. Jiang, J. Kim, 2011, ISBN 978-1-60511-373-9

Volume 1397E - Ferroelectric and Multiferroic Materials, M. Bibes, C.J. Fennie, L.W. Martin, B. Noheda, T. Kimura, 2011, ISBN 978-1-60511-374-6

Volume 1398E - Magnetoelectric Composites, P. Finkel, 2011, ISBN 978-1-60511-375-3

Volume 1399E - Compliant Electronics and Photonics, D. Tyler, 2011, ISBN 978-1-60511-376-0

Volume 1400E - Solution Processing of Inorganic and Hybrid Materials for Electronics and Photonics, P.J. Smith, M.F.A.M. van Hest, D.B. Mitzi, A. Morrin, 2011, ISBN 978-1-60511-377-7

Volume 1401E - Large-Area Processing and Patterning for Active Optical and Electronic Devices III, I. Kymissis, T. Anthopoulos, C. Madigan, M. Shtein, 2011, ISBN 978-1-60511-378-4

Volume 1402E - Charge Generation/Transport in Organic Semiconductor Materials, J. Anthony, 2011, ISBN 978-1-60511-379-1

Volume 1403 - Multifunctional Polymer-Based Materials, A. Lendlein, Y. Feng, T. Xie, Z. Guan, 2011, ISBN 978-1-60511-380-7

Volume 1404E - Phonons in Nanomaterials-Theory, Experiments and Applications, S.L. Shinde, D.H. Hurley, G.P. Srivastava, M. Yamaguchi, 2011, ISBN 978-1-60511-381-4 


\section{Materials Research Society Symposium ProceedingS}

Volume 1405E - Advances in Energetic Materials Research, M.R. Manaa, C-S. Yoo, E.J. Reed, M.S. Strano, 2011, ISBN 978-1-60511-382-1

Volume 1406 - Functional Metal-Oxide Nanostructures, A. Vomiero, S. Mathur, Z.L. Wang, E. W-G. Diau, 2011, ISBN 978-1-60511-383-8

Volume 1407 - Carbon Nanotubes, Graphene and Related Nanostructures, Y.K. Yap, D. Futaba, A. Loiseau, M. Zheng, 2011, ISBN 978-1-60511-384-5

Volume 1408 - Functional Nanowires and Nanotubes, K. Nielsch, A.F. i Morral, H. Linke, H. Shin, L. Shi, 2011, ISBN 978-1-60511-385-2

Volume 1409E - Functional Semiconductor Nanocrystals and Metal-Hybrid Structures, K.S Leschkies, P. Nagpal, M.A. Pelton, H. Mattoussi, P. Kambhampati, 2011, ISBN 978-1-60511-386-9

Volume 1410E - Transport Properties in Polymer Nanocomposites II, S. Nazarenko, J. Grunlan, J. Bahr, E. Espuche, 2011, ISBN 978-1-60511-387-6

Volume 1411E - Self Organization and Nanoscale Pattern Formation, S. Persheyev, 2011, ISBN 978-1-60511-388-3

Volume 1412E - Mechanical Nanofabrication, Nanopatterning and Nanoassembly, G. Cross, A. Schirmeisen, A. Knoll, M. Rolandi, 2011, ISBN 978-1-60511-389-0

Volume 1413E - Safety and Toxicity Control of Nanomaterials, W.W. Yu, V.L. Colvin, Q. Dai, P.C. Howard, 2011, ISBN 978-1-60511-390-6

Volume 1415 - MEMS, BioMEMS and Bioelectronics-Materials and Devices, T. Albrecht, M.P. de Boer, F.W. DelRio, M.R. Dokmeci, C. Eberl, J. Fukuda, H. Kaji, C. Keimel, A. Khademhosseini, 2011, ISBN 978-1-60511-392-0

Volume 1416E - Nanofunctional Materials, Nanostructures and Nanodevices for Cancer Applications, S. Svenson, P. Grodzinski, S. Manalis, X J. Liang, W. Lin, 2011, ISBN 978-1-60511-393-7

Volume 1417E - Biomaterials for Tissue Regeneration, C.C. Sorrell, 2011, ISBN 978-1-60511-394-4

Volume 1418 - Gels and Biomedical Materials, F. Horkay, R. Narayan, V. Dave, S. Jin, N. Langrana, J.D. Londono, W. Oppermann, S. Ramakrisha, D. Shi, R.G. Weiss, 2011, ISBN 978-1-60511-395-1

Volume 1419E - Nucleation and Growth of Biological and Biomimetic Materials, P.M. Rodger, J. Harding, L.B. Gower, P. Vekilov, 2011, ISBN 978-1-60511-396-8

Volume 1420E - Multiscale Mechanics of Hierarchical Materials, F. Barthelat, 2011, ISBN 978-1-60511-397-5

Volume 1421E - Three-Dimensional Tomography of Materials, S. Pennycook, 2011, ISBN 978-1-60511-398-2

Volume 1422E - Functional Imaging of Materials-Advances in Multifrequency and Multispectral Scanning Probe Microscopy and Analysis, A. Baddorf, 2011, ISBN 978-1-60511-399-9

Volume 1423E - Dynamics in Confined Systems and Functional Interfaces, M.H. Müser, D.L. Irving, S.B. Sinnott, I. Szlufarska, 2011, ISBN 978-1-60511-400-2

Volume 1424 - Properties and Processes at the Nanoscale-Nanomechanics of Material Behavior, D. Bahr, P. Anderson, N. Moody, R. Spolenak, 2011, ISBN 978-1-60511-401-9

Volume 1425E - Combinatorial and High-Throughput Methods in Materials Science, J.B. Miller, J. Genzer, Y. Matsumoto, R.A. Potyrailo, 2011, ISBN 978-1-60511-402-6

Prior Materials Research Society Symposium Proceedings available by contacting Materials Research Society 